\title{
Histopathological characterization of Coffea arabica cultivar IPR 106 resistance to Meloidogyne paranaensis
}

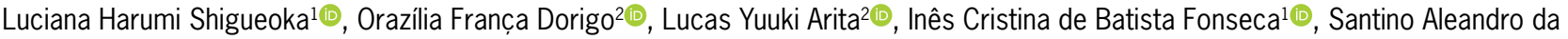 \\ Silva $^{20}$, Gustavo Hiroshi Sera ${ }^{3(0)}$, Andressa Cristina Zamboni Machado*(i)
}

\author{
'Universidade Estadual de Londrina - Depto. de Agronomia, \\ Rod. Celso Garcia Cid, Pr 445, km 380 - 86057-970 - \\ Londrina, PR - Brasil. \\ 2Instituto Agronômico do Paraná - Depto. de Proteção de \\ Plantas, Rod. Celso Garcia Cid, km 375 - 86047-902 - \\ Londrina, PR - Brasil. \\ Innstituto Agronômico do Paraná - Depto. de Melhoramento \\ e Genética Vegetal. \\ *Corresponding author <andressaczmachado@hotmail.com>
}

Edited by: Roy Neilson

Received January 05, 2018

Accepted April 26, 2018
ABSTRACT: Meloidogyne species are widely distributed in coffee growing areas in Brazil, where M. paranaensis is responsible to significant losses to the crop. One of the main management strategies is the use of resistant cultivars, such as Apoatã rootstock and cultivars IPR 100 and IPR 106. However, the parasitic relationship between coffee and M. paranaensis in cultivars carrying resistance genes has been poorly understood. The objective of this paper was to characterize the resistance response of Coffea arabica cv. IPR 106 to M. paranaensis. For this, penetration and histopathological studies were carried out using root tissues parasitized by the nematode. 'IPR 106' and 'Mundo Novo' (susceptible cultivar) seedlings were inoculated with 4,000 eggs of $M$. paranaensis and, 15 days after inoculation (DAl), roots were stained with fuchsine to verify the penetration rates of the nematode. Histopathological studies were conducted at 15, 30, 45 and 60 DAl and nematode reproduction was calculated at 120 DAl. 'IPR 106' did not avoid completely nematode penetration at $15 \mathrm{DAl}$, although the number of nematodes was $50 \%$ lower than in Mundo Novo, disregarding the hypothesis of a pre-infectional mechanism of resistance that could prevent nematode penetration completely. However, giant cells and collapsed nematodes were observed in 'IPR 106' at 30 DAl, suggesting that the resistance mechanism to M. paranaensis in 'IPR 106' involves a post-infectional response and could be mediated by a hypersensitive reaction.

Keywords: management, root-knot nematodes, giant cells

\section{Introduction}

Nematodes of Meloidogyne genera Chitwood, 1949, are widely distributed in coffee growing areas in Brazil, where M. paranaensis, Carneiro et al., 1996, accounts for significant losses to the crop (Campos and Villain, 2005). In Paraná State, Brazil, M. paranaensis is widespread in coffee crops and have a high economic impact on production (Ferraz, 2008). Still, comprehensive assessments of the damage caused by this nematode have not been undertaken. Meloidogyne spp. are sedentary endoparasites that show complex interactions with their hosts, inducing the establishment of highly specialized giant cells and closely associated to the vascular system of plant root system (Bird, 1961). These cells are responsible for pathogen nutrition during its life cycle (Abad et al., 2009).

One of the main management strategies in coffee crops is the use of resistant cultivars, which decreases nematode reproduction rates and reduce nematode populations in the soil, especially when integrated with other strategies, such as crop rotation with non-hosts (Roberts, 2002).

Although resistance sources to nematodes exist in some Coffea species (Sera et al., 2006), few commercial C. arabica resistant cultivars are available. 'IPR 100' and 'IPR 106' are some of the scarce $C$. arabica cultivars that carry resistance genes from $C$. liberica and C. canephora, respectively (Ito et al., 2008; Sera et al., 2017).
Plant resistance mechanisms to nematode infection involve pre- or post-infectional reactions (Huang, 1985; Marini et al., 2016). One of the mechanisms involved is the hypersensitive reaction (HR), which induces histological changes after nematode penetration in root tissues, such as the death of the cells close to the giant cell induced by the nematode (Anthony et al., 2005; Albuquerque et al., 2010; Silva et al., 2013; Marini et al., 2016). Several works have been published describing the relationships between coffee and root-knot nematodes, particularly to $M$. incognita (Albuquerque et al., 2010) and M. exigua (Rodrigues et al., 2000; Anthony et al., 2005). For both nematode species, authors reported a hypersensitive-like response of infested cells in resistant cultivars. However, parasitism of $M$. paranaensis in coffee cultivars carrying resistance genes has been poorly explored.

Thus, this study aimed to evaluate the resistance responses of $C$. arabica cv. IPR 106 to $M$. paranaensis. Penetration studies were conducted to observe a possible pre-infectional resistance mechanism in addition to histopathological observations of root tissues parasitized by the nematode to clarify the post-infectional resistance mechanism associated or not to a hypersensitive reaction.

\section{Materials and Methods}

Two experiments were conducted in a greenhouse in Londrina, Paraná State, Brazil (2318'36" S; 51 09'46" $\mathrm{W}$; and altitude $610 \mathrm{~m}$ ), from 06 Jan to 06 Mar 2016 
and from 21 Mar to 25 July 2016. Temperatures ranged from $20^{\circ} \mathrm{C}$ to $46^{\circ} \mathrm{C}$ in experiment 1 and from $20^{\circ} \mathrm{C}$ to $34{ }^{\circ} \mathrm{C}$ in experiment 2 (replica). The experiments were conducted in a completely randomized design, with four replicates to each cultivar and evaluation time.

The $M$. paranaensis population used as inoculum in the experiments was originally obtained from coffee roots collected in the municipality of Apucarana

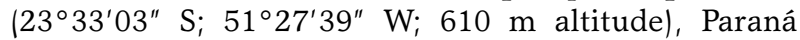
State, Brazil. This population was identified based on $\alpha$-esterase phenotype (Carneiro and Almeida, 2001) and perineal pattern (Hartman and Sasser, 1985). Subsequently, a unique egg mass was separated for inoculum preparation. The population was kept in coffee plants cv. Mundo Novo under greenhouse conditions during the experiment. Approximately 60 days before inoculation, nematodes were extracted from coffee roots (Boneti and Ferraz, 1981) and inoculated in tomato plants cv. Santa Clara to multiply the inoculum for the experiments.

Seeds of C. arabica cv. Mundo Novo (susceptible) and IPR 106 (resistant) were sown in plastic trays containing sterilized sandy, under greenhouse conditions. After germination, cotyledon seedlings were transplanted to tubes $(125 \mathrm{~mm} \times 34 \mathrm{~mm})$ containing $180 \mathrm{~cm}^{3}$ of commercial substrate to complete their development until the 1-leaf stage, when they were able to be inoculated. Plants were irrigated as necessary and fertilized once during the experimental period with $3 \mathrm{~g}$ of Osmocote Plus (15\% N, $9 \% \mathrm{P}_{2} \mathrm{O}_{5}, 12 \% \mathrm{~K}_{2} \mathrm{O}, 1 \% \mathrm{Mg}, 2.3 \% \mathrm{~S}$, $0.05 \% \mathrm{Cu}, 0.45 \% \mathrm{Fe}, 0.06 \% \mathrm{Mn}, 0.02 \% \mathrm{Mo})$.

\section{Penetration and histopathological studies}

Seedlings of cultivars Mundo Novo and IPR 106 were inoculated with a suspension containing 4,000 eggs of $M$. paranaensis, extracted according to the methodology of Boneti and Ferraz (1981). Nematode penetration was assessed at 15 days after inoculation (DAI), when plants were removed from pots and root systems, carefully washed and stained with acid fuchsine (Byrd et al., 1983). The entire root system of each plant was examined under a light microscope at $10 \times$ magnification. Penetration and nematodes development were evaluated by counting the stained second-stage juveniles (J2) or the number of $\mathrm{J} 3, \mathrm{~J} 4$, immature or mature females found in the roots, respectively.

For the histopathological studies, four plants of each cultivar were evaluated at 15, 30, 45, and 60 DAI. For each plant, a set of root segments was excised, fixed and embedded in the epoxy resin Technovit 7100 (Kulzer, Friedrichsdorf, Germany) according to Pegard et al. (2005). Embedded samples were sectioned in $5.0 \mu \mathrm{m}$ slices and stained with $0.5 \%$ toluidine blue in $0.1 \mathrm{M}$ sodium phosphate buffer, $\mathrm{pH} 5.5$ and observed under a light microscope. Histopathological features from approximately 4,000 root sections were observed in both susceptible and resistant coffee cultivars inoculated with $M$. paranaensis at $15,30,45$, and 60 DAI.

\section{Host reaction of coffee cultivars Mundo Novo and IPR 106 to M. paranaensis}

Six plants of each cultivar from the penetration and histopathological studies were separated and kept under greenhouse conditions to evaluate nematode reproduction. At $60 \mathrm{DAI}$, when plants were in the 5-leaf stage, shoot tips were removed and discarded and root systems were washed with tap water and dried on absorbent paper to determine values of fresh weight and, subsequently, the roots were cut into $1-\mathrm{cm}$ pieces. The entire root system of each replicate was processed for egg extraction (Boneti and Ferraz, 1981). Nematode final population was estimated by counting eggs and eventual juveniles from parasitized roots with a Peter's slide. The values of the reproduction factor $(\mathrm{RF})(\mathrm{RF}=$ Final Population/Initial Population) were subsequently determined (Oostenbrink, 1966). Number of nematodes per gram of roots $\left(\mathrm{Nema}^{-1}\right)$ were also calculated for each replicate.

\section{Data analyses}

Penetration and reproduction of $M$. paranaensis in coffee plants were evaluated and histopathological studies were conducted in two experiments arranged in a completely randomized design, with two treatments (cvs. Mundo Novo and IPR 106) and four (penetration and histopathological studies) or six (reproduction) replicates each. The similarity between both experiments was tested by preliminary ANOVA using experimental runs as factors to determine experiment $\times$ treatment interaction. This interaction was not significant and allowed data combination for the analysis. The data set was analyzed by the Levene's (homogeneity) and Shapiro-Wilk (normality) tests. Later, treatments were compared by the $\mathrm{T}$ test $(p<0.05)$ using software $\mathrm{R}$ ( R Core Team, version 2.15.2).

\section{Results}

A larger number of individuals at $\mathrm{J} 2, \mathrm{~J} 3, \mathrm{~J} 4$, and immature females were observed in Mundo Novo at 15 DAI than in IPR 106 (Figure 1) in stained roots. Mature females were observed in both cultivars at a smaller number, due to the early evaluation time.

At 15 DAI, transverse sections of roots showed that the nematode started its parasitism in both cultivars, since parasitic J2 and J3 were found in susceptible and resistant cultivars, surrounded by hypertrophied, asymmetrical cells induced by the nematodes (Figures $2 \mathrm{~A}$ and $2 \mathrm{~B}$ ). These giant cells contained a cytoplasm characteristically vacuolated, dense and multinucleated. In "Mundo Novo", besides the presence of J2 and J3 in the cortex, J3 and J4 presented conspicuous giant cells associated. These giant cells were also vacuolized and showed dense and multinucleated cytoplasm.

At $30 \mathrm{DAI}$, an initial evidence of resistance reaction to nematode was observed in 'IPR 106', with abnormal giant cells and malformed females (Figure 2C). In 'Mundo Novo', immature and mature females were 


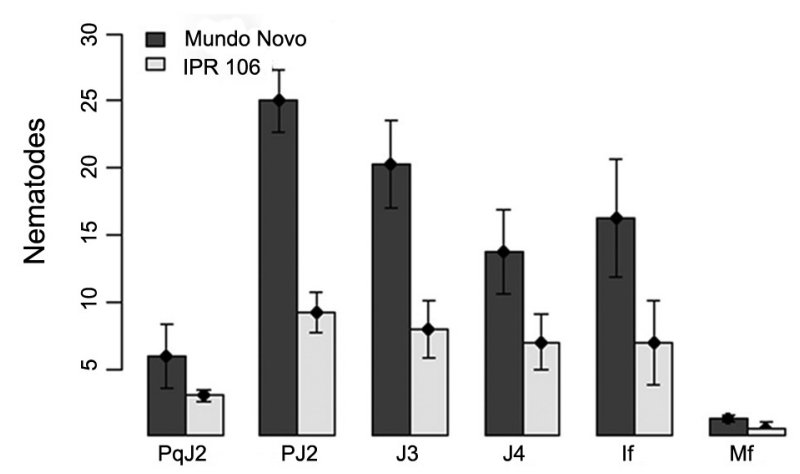

Figure 1 - Schematic representation of the mean number of specimens of Meloidogyne paranaensis in roots of coffee cultivars IPR 106 (resistant) and Mundo Novo (susceptible), at different life stages, at 15 days after inoculation. Data are the average of two experiments with four replicates. Significant differences were found between parasitic $\mathrm{J} 2$ and $\mathrm{J} 3$ stages in both cultivars according to the $T$ test $(p<0.05)$. PpJ2 = pre-parasitic J2; PJ2 = parasitic $\mathrm{J} 2$; If = immature female; $\mathrm{Mf}=$ mature female.

observed surrounded by typical giant cells (Figure 2D). The enlargement of the vascular cylinder region induced symptoms of root thickenings in this cultivar.

At 45 and 60 DAI (Figures $2 \mathrm{E}$ and $2 \mathrm{G}$ ), a resistance reaction could be visualized in 'IPR 106', with abnormal or degenerated giant cells and collapsed nematodes. Dark cells were observed associated to a hypersensitive-like reaction and cell death. In 'Mundo Novo', both at 45 and 60 DAI (Figures $2 \mathrm{~F}$ and $2 \mathrm{H}$ ), mature females were observed with expanded ovaries, but without egg masses. Giant cells were well developed with dense and granular cytoplasm and multiple nuclei.

Regarding nematode reproduction in IPR 106 and Mundo Novo (Table 1), as expected, cultivar Mundo Novo allowed a higher multiplication of $M$. $p a-$ ranaensis, when compared with IPR 106 ( $\mathrm{RF}=2.21$ and 0.07, respectively), according to the T test $(p<$ $0.05)$. In general, the number of nematodes per gram of roots (Nema g-1) (Table 1) corroborated the RF values $\left(\right.$ Nema $\mathrm{g}^{-1}=3,272$ and 86, respectively, for Mundo Novo and IPR 106).

\section{Discussion}

Juveniles of Meloidogyne paranaensis penetrated root tissues in susceptible and resistant cultivars, although at a lower range in IPR 106, at 15 DAI. In 'IPR $106^{\prime}$, the number of nematodes inside the roots was 50 $\%$ lower than in Mundo Novo, which eliminates the hypothesis of a pre-infectional mechanism of resistance that could prevent nematode penetration completely. At $30 \mathrm{DAI}$, an initial evidence of resistance reaction to nematode was observed in IPR 106, while at 45 and 60 DAI, degenerated giant cells and collapsed nematodes were visualized in this cultivar. This fact suggested that
Table 1 - Reproduction factor (RF) and number of nematodes per gram of roots (Nema $\mathrm{g}^{-1}$ ) of Meloidogyne paranaensis in coffee plants cultivars Mundo Novo (susceptible) and IPR 106 (resistant), at 60 days after inoculation.

\begin{tabular}{lcc}
\hline Cultivar & RF & Nema g-1 $^{-1}$ \\
\hline Mundo Novo & $2.21(0.74)$ & $3,272(1,159.29)$ \\
IPR 106 & $0.07(0.01)$ & $86(11.85)$
\end{tabular}

Data are the average of two experiments with six replicates. Significant differences were found between cultivars in relation to nematode multiplication according to the T test $(p<0.05)$. Data in parentheses are the standard errors.

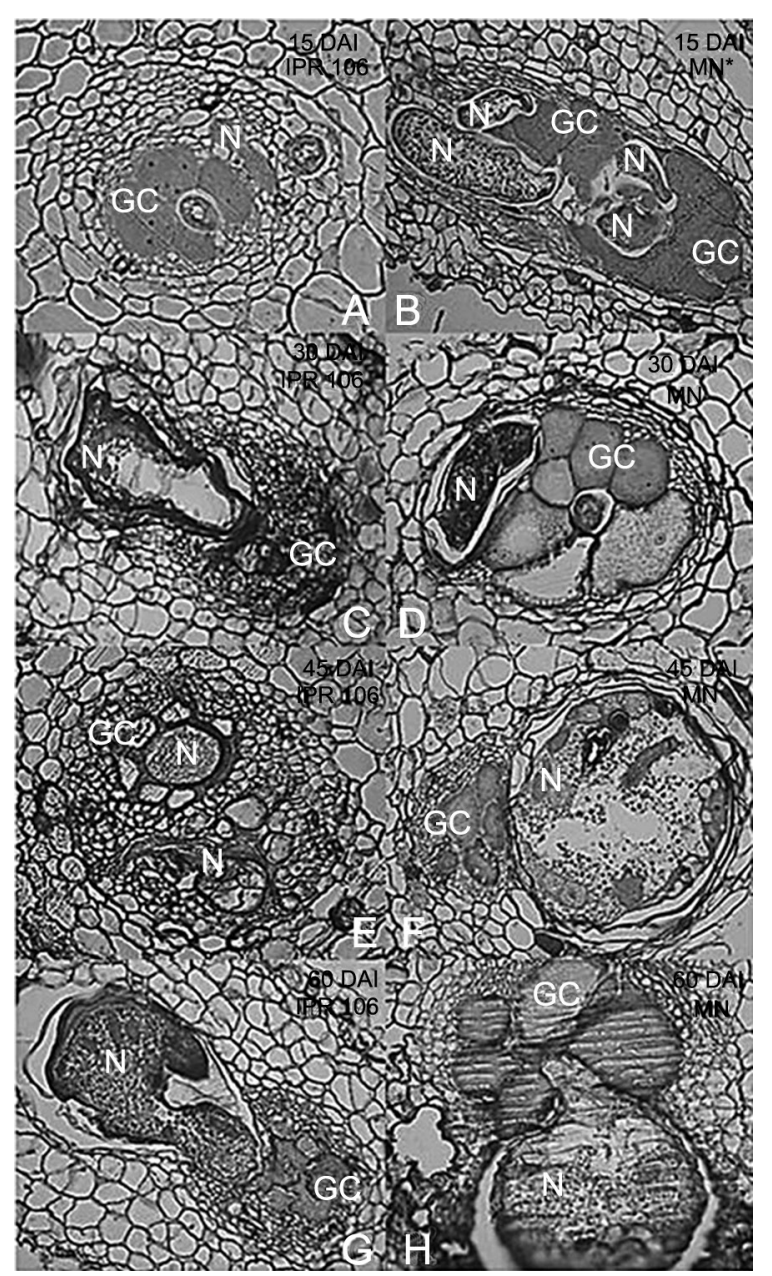

Figure 2 - Interaction between coffee cultivars IPR 106 (resistant) and Mundo Novo ( ${ }^{*} \mathrm{MN}$ ) (susceptible) inoculated with Meloidogyne paranaensis under light microscopy. (A and B) J2/J3 and giant cells, in IPR 106 and Mundo Novo; (C) disorganized cells in IPR 106, with tissue darkening and cell death next to a degenerated J4; (D) giant cell with granular and multinucleated cytoplasm associated to a welldeveloped J4 in Mundo Novo; (E) poor developed giant cell associated to cell disorganization and degenerated immature female in IPR 106; (F) well-developed giant cell and mature female completely developed in Mundo Novo; (G) poorly developed giant cell, with disorganized and death cells, and degenerated female in IPR 106; (H) giant cells and mature female in Mundo Novo. $\mathrm{N}=$ nematode; $\mathrm{GC}=$ giant cells. 
the resistance mechanism to M. paranaensis in 'IPR 106' involves a post-infectional response probably mediated by a hypersensitive-like reaction, although it did not prevent penetration completely. In this work, IPR 106 was classified as a resistant cultivar to $M$. paranaensis at $60 \mathrm{DAI}$, corroborating previous reports from Ito et al. (2008), who observed a resistance reaction of this cultivar to $M$. paranaensis and $M$. incognita.

Silva et al. (2013) compared the penetration of $M$. exigua in cultivars Apoatã IAC 2258 (resistant) and Catuaí Vermelho IAC 44 (susceptible) and observed females and eggs in the root cortex of Catuaí Vermelho IAC 44 at 30 DAI. In the cultivar Apoatã IAC 2258, adult females were observed only from $40 \mathrm{DAI}$, without impediment to nematode penetration, as observed for $M$. paranaensis and 'IPR 106' in this study.

Meloidogyne incognita caused root galls at 14 DAI in cultivar Catuaí Vermelho IAC 15 (susceptible), where $\mathrm{J} 3$ and J4 were found in the roots (Albuquerque et al., 2010). In this study, females were found in the central cylinder of roots at $34 \mathrm{DAI}$, with damages to parenchyma and vascular tissues, visualized by the presence of dark spots in the tissues besides cellular collapse. These results are similar to our observations for Mundo Novo, where J3/J4 and immature females were observed at 15 DAI and adult females at 30 DAI.

The resistance mechanism of IPR 106 to $M$. paranaensis is probably associated to post-infectional events. Poorly developed or degenerated giant cells were observed from 30 DAI in IPR 106. Establishment and maintenance of giant cells are essential for nematode parasitism, both for complete development and reproduction (Abad et al., 2009). In some resistant plants, nutrients or essential substances to nematode establishment may be scarce, resulting in emigration or delay in nematode development (Silva et al., 2013).

For the interaction between resistant coffee (IAPAR 59) and $M$. exigua, a post-infectional defense response was observed by Anthony et al. (2005), leading the authors to suggest the presence of a hypersensitivelike reaction (HR) in the interaction between coffee and M. exigua. Similarly, Lima et al. (2015) characterized histologically the mechanisms involved in resistance of "Clone 14" from C. canephora to M. paranaensis and also visualized a hypersensitive-like reaction in this interaction, as observed in IPR 106 in our work.

The dark color of cells near the giant cells produced by $M$. paranaensis in IPR 106, from 30 DAI, characterizing necrosis and cellular degenerations could also represent a HR. However, detailed studies are necessary to prove this observation. HR represents one of the main plant defense mechanisms, causing histological changes after nematode penetration in coffee roots, with cell death near the J2 infection point (Silva et al., 2013). HR reactions are frequently accompanied by cell death surrounding nematode penetration, during its migration or after the establishment of the giant cell (Rodrigues et al., 2000; Marini et al., 2016).
Therefore, the present results suggest that the resistance mechanism of IPR 106 to $M$. paranaensis occurs through a post-infectional mechanism probably involving a hypersensitive reaction.

\section{Authors' Contributions}

Conceptualization: Machado, A.C.Z.; Sera, G.H. Data acquisition: Shigueoka, L.H.; Arita, L.Y.; Silva, S.A.; Dorigo, O.F. Data analysis: Silva, S.A.; Fonseca, I.C.B. Design of methodology: Machado, A.C.Z.; Silva, S.A.; Fonseca, I.C.B. Writing and editing: Machado, A.C.Z.; Shigueoka, L.H.; Sera, G.H.

\section{References}

Abad, P.; Castagnone-Sereno, P.; Rosso, M.N.; Engler, J.A.; Favery, B. 2009. Invasion, feeding and development. p. 163181. In: Perry, R.N.; Moens, M.; Starr, J.L., eds. Root- knot nematodes. CABI International, Wallingford, UK.

Albuquerque, E.V.S.; Carneiro, R.M.D.G.; Costa, P.M.; Gomes, A.C.M.M.; Santos, M.; Pereira A.A.; Nicole, M.; Fernandez, D.; Grossi-de-Sá, M.F. 2010. Resistance to Meloidogyne incognita expresses a hypersensitive-like response in Coffea arabica. European Journal of Plant Pathology 127: 365-373. DOI: $10.1007 / \mathrm{s} 10658-010-9603-3$.

Anthony, F.; Topart, P.; Martinez, A.; Silva, M.; Nicole, M. 2005. Hypersensitive-like reaction conferred by de Mex-1 resistance gene against Meloidogyne exigua in coffee. Plant Pathology 54: 476-482. DOI: 10.1111/j.1365-3059.2005.01239.x.

Bird, A.F. 1961. The ultrastructure and histochemistry of a nematode-induced giant cell. Journal of Biophysical and Biochemical Cytology 11: 701-705.

Boneti, J.I.; Ferraz, S. 1981. Modification of the Hussey \& Barker method for extracting Meloidogyne exigua eggs from coffee roots $=$ Modificações no método Hussey \& Barker para extração de ovos de Meloidogyne exigua, em raízes de cafeeiro. Fitopatologia Brasileira 6: 533 (in Portuguese).

Byrd, D.W.; Kirpatrick, T.; Barker, K.R. 1983. An improved technique for clearing and staining plant tissue for detection of nematodes. Journal of Nematology 15: 142- 143.

Campos, V.P.; Villain, L. 2005. Nematode parasites of coffee, cocoa and tea. p. 529-579. In: Luc, M.; Sikora, R.A.; Bridge, J. eds. Plant parasitic nematodes in subtropical and tropical agriculture. CAB International, Wallingford, UK.

Carneiro, R.M.D.G.; Almeida, M.R.A. 2001. Electrophoretic technique used in the study of root-knot nematode enzymes for species identification. Nematologia Brasileira 25: 35-44 (in Portuguese, with absctract in English).

Ferraz, L.C.C.B. 2008. Brazil. p. 225-248. In: Souza, R.M., ed. Plant-parasitic nematodes of coffee. Springer, Berlin, Germany.

Hartman, R.M.; Sasser, J.N. 1985. Identification of Meloidogyne species on the basis of differential host and perineal pattern morphology. p. 69-77. In: Barker, K.R.; Carter, C.C.; Sasser, J.N., eds. An advanced treatise on Meloidogyne. North Carolina State University, Raleigh, NC, USA. 
Huang, C.S. 1985. Formation, anatomy and physiology of giant cells induced by root-knot nematodes. p. 155-164. In: Barker, K.R.; Sasser, J.N.; Carter, C.C., eds. An advanced treatise on Meloidogyne. North Carolina State University, Raleigh, NC, USA.

Ito, D.S.; Sera, G.H.; Sera, T.; Santiago, D.C.; Kanayama, F.S.; Del Grossi, L. 2008. Progenies of coffee with resistance to nematode Meloidogyne paranaensis and Meloidogyne incognita race 2. Coffee Science 3: 156-163 (in Portuguese, with abstract in English).

Lima, E.A.; Furlanetto, C.; Nicole, M.; Gomes, A.C.M.M.; Almeida, M.R.A.; Jorge-Junior, A.; Correa, V.R.; Salgado, S.M.; Ferrão, M.A.; Carneiro, R.M.D.G. 2015. The multiresistant reaction of drought-tolerant coffee 'Conilon Clone 14 ' to Meloidogyne spp. and late hypersensitive-like response in Coffea canephora. Phytopathology 105: 805-814. DOI: 10.1094/ PHYTO-08-14-0232-R.

Marini, P.M.; Garbuglio, D.D.; Dorigo, O.F.; Machado, A.C.Z. 2016. Histological characterization of resistance to Meloidogyne incognita in Avena sativa. Tropical Plant Pathology 41: 203-209. DOI: $10.1007 / \mathrm{s} 40858-016-0088-2$.

Oostenbrink, M. 1966. Major characteristics of the relation between nematodes and plants. Mendelingen Landbouwhogeschool Wageningen 66: 1-46.

Pegard, A.; Brizzard, G.; Fazari, A.; Soucaze, O.; Abad, P.; DijanCaporalino, C. 2005. Histological species related to phenolics accumulation in Capsicum annum. Phytopathology 95: 158-165. DOI: 10.1094/PHYTO-95-0158.
Roberts, P.A. 2002. Concepts and consequences of resistance. p. 23-41. In: Starr, J.L.; Cook, R.; Bridge, J., eds. Plant resistance to parasitic nematodes. CAB International, Wallingford, UK. DOI: $10.1079 / 9780851994666.0023$.

Rodrigues, A.C.F.O.; Abrantes, I.M.O.; Melillo, M.T.; Blevezacheo, T. 2000. Ultrastructural response of coffee roots to root-knot nematodes, Meloidogyne exigua and M. megadora. Nematropica 30: 201-210.

Sera, G.H.; Sera, T.; Azevedo, J.A.; Mata, J.S.; Ribeiro-Filho, C.; Doi, D.S.; Ito, D.S.; Fonseca, I.C.B. 2006. Robusta coffee rootstocks resistant to Meloidogyne paranaensis and M. incognita races 1 and 2. Semina: Ciências Agrárias 27: 171-184 (in Portuguese, with abstract in English).

Sera, T.; Sera, G.H.; Fazuoli, L.C.; Machado, A.C.Z.; Ito, D.S.; Shigueoka, L.H.; Silva, S.A. 2017. IPR 100: rustic dwarf Arabica coffee cultivar with resitance to nematodes Meloidogyne paranaensis and M. incognita. Crop Breeding and Applied Biotechnology 17: 175-179. DOI: 10.1590/1984$70332017 \mathrm{v} 17 \mathrm{n} 2 \mathrm{c} 26$

Silva, R.V.; Oliveira, R.D.L.; Ferreira, O.S.; Ferreira, A.O.; Rodrigues, F.A. 2013. Defense responses to Meloidogyne exigua in resistant coffee cultivar and non-host plant. Tropical Plant Pathology 38: 114-121. DOI: 10.1590/S198256762013000200004 . 